2018, Vol. 04(2) 51-69

\title{
Relation between Sectoral Distribution of Commercial Bank Credit and Economic Growth in Sri Lanka
}

\author{
V. Muthusamy \\ Sabaragamuwa University Sri Lanka, Sri Lanka \\ N. J. Dewasiri \\ University of Sri Jayewardenepura, Sri Lanka \\ Y. K. B. Weerakoon \\ University of Sri Jayewardenepura, Sri Lanka
}

\section{A. A. M. D. Amarasinghe}

Sabaragamuwa University Sri Lanka, Sri Lanka

\section{Abstract}

This study investigates the impact of sectoral distribution of commercial bank credit on economic growth in Sri Lanka based on data from 2005 to 2017. The Auto-regressive Distributed Lag (ARDL) model is used to investigate short and long run impact of sectoral distribution of commercial bank credit on Gross Domestic Product (GDP). The findings of the ARDL Error Correction model indicate that the commercial bank sectoral credit distribution is significantly explaining the short run economic growth. Moreover, ARDL long run form and bounds test shows that there is a long run relation between the variables. The industrial sector has a long run positive relationship with GDP while the other sectors are insignificant in explaining long run economic growth. According to the results, the government can motivate banks to distribute credit facilities to the industry sector to boost GDP in the long-run. This is the first study that discusses the

\section{Corresponding Author:}

Ms. V. Muthusamy is a Lecturer at the Department of Accountancy and Finance, Faculty of Management Studies, Sabaragamuwa University of Sri Lanka, Sri Lanka. E-mail: mttii@gmail.com 
sectoral distribution of commercial bank credit on economic growth of Sri Lanka as per the best of the authors' knowledge.

\section{Keywords}

Commercial bank, Credit, Economic growth, Gross Domestic Product

\section{Introduction}

A commercial bank's primary function is defined as acquiring funds from surplus units in term of deposits and lending them to all legitimate businesses and consumer financial needs with a competitive interest rate (Rose, 2002). The commercial banks extend loans and advances to different sectors such as agriculture, service and industry to enhance the sustainability of an economy. The previous literature emphasizes that the commercial bank-private sector lending play a vital role to enhance the economic growth of a country (Köhler, 2015; Chinweoke, Chukwudinma, \& Elizabeth 2015).

There is a contradiction in the findings of impact of sectoral distribution of commercial bank credit on the economic growth as indicated in the studies conducted in the past few decades (Waheed, 2009; Uzomba, Chukwu, Jumbo, \& Nwankwo, 2014; Mulu, 2012). For instance, Köhler (2012) argued that there is an inverse relationship between credit facilities to the real sectors (i.e. all the sectors) and productivity of an economy. Contrary to Köhler's (2012) findings, Burzynska (2009) stated that the economy has a one-way causality between economic growth and loans to the commercial sector while Mulu (2012) arguing that a banking sector credit facility does not contribute to the economic growth. Moreover, most of the studies individually investigated credit facilities distributed to a single sector and its impact on economic growth of the respective country (Mulu, 2012; Burzynska, 2009; Hartarska, Nadolnyak, \& Shen, 2015; Ghosh, 2016).

The present context of the Sri Lankan economy indicates that, commercial banks and the stock market are challenged by negative macroeconomic conditions (Dewasiri \& Kumarasinghe, 2014). The lending profits dropped in 2017, the GDP indicated a lower growth rate due to the adverse impact of weather conditions, tax adjustments and rising international commodity prices in 2017 (Central Bank of Sri Lanka[CBSL], 
2017). Moreover, the Sri Lankan currency rate has also shown a depreciating trend in the market (Rajakaruna, 2017). The regulatory body tightened the fiscal and monetary policy to overcome these problems. As a result, the standing lending facility rate (SLRF) increased up to 8 percent in 2016 (Rajakaruna, 2017). In view of above facts, the banking sector is still addressing the real sectors' monetary requirements through its operations in an unfavourable environment. In general, the Sri Lankan commercial bank loans and advance facilities dropped for the industrial and agricultural sectors across past few years. Meanwhile the service sector recorded a positive credit expansion (CBSL, 2017).

The present study is different from aforementioned studies (Mulu, 2012; Burzynska, 2009; Hartarska et al., 2015; Ghosh, 2016) since it focuses on a holistic view focusing agricultural, industrial, personal consumption, and service sectors in a single study. Moreover, there is a paucity of studies conducted in the Sri Lankan context on the same phenomenon. Hence, the contradictions in the findings of the previous studies and paucity of studies conducted in the Sri Lankan context have motivated this study to a great extent. Thus, this research is aimed to contribute to the existing literature, filling the aforementioned research gaps of contradictory findings and paucity of studies conducted in the Sri Lankan context. Thereby, the research problem of this study is identified as "What is the impact of sectoral credit distribution of commercial bank credit on the economic growth of Sri Lanka?"

The objectives of this study are [1] to examine the short-term impact of sectoral distribution of commercial bank credit on economic growth, [2] to investigate the long run relation between sectoral distribution of commercial bank credit and economic growth in Sri Lanka.

\section{Literature Review}

A sound and resilient banking system empowers a country's real sector. Rahman, Jongwanich, Venkatesh, and Siengthai (2012) emphasized that "a banking system should be more concerned about environment shocks to safeguard the financial system as well as the productivity of a country". The theoretical background of the study is explained through the Cobb-Douglas theory which explains the relationship between labour supply, capital, and 
production. The production represents economic growth and credit borrowings are considered as a proxy to represent the capital under the assumption of debt (Mulu, 2012). Thus, the Cobb-Douglas theory has implications for the current study since credit borrowing is related to economic growth as emphasized by Mulu (2012). Moreover, Solow (1956) proposed another explanation on economic growth stating that the long run economic growth as a result of capital accumulation, labour (population) growth, and the increases in productivity. Here, the credit distribution to the real sector has implication to capital accumulation (in terms of debt capital). Hence, the Robert Solow Model of Growth is also having implications for this study.

Empirical studies revealed contrary findings on the relation between sectoral credit distribution and economic growth. For instance, Burzynska (2009) employed an empirical framework using Johansen Co-integration technique to investigate the long-term relationship between Chinese economic growth and sectoral distribution of credit facilities. Burzynska (2009) stated that the banking industry extensively supports the economy with banking credit facilities. Moreover, Burzynska (2009) and Galeano $\&$ Feijo (2012) further explained the different types of loans and advance products from different banks that have a positive impact on economic growth. Contrary to Burzynska's (2009) and Galeano \& Feijo's (2012) findings, Mulu (2012) argued that the banking sector credit facilities do not contribute to economic growth. Mulu (2012) explained that supply and demand of the credit products are statistically significant but the association between sectoral distribution of credit facilities and economic growth reflect a slight negative and insignificant association. Hence, Mulu (2012) concluded that sectoral distribution of bank credit facilities does not significantly contribute to enhance productivity.

Chinweoke et al. (2015) stated that commercial banks play an auxiliary role in developing the real sectors to achieve outstanding economic growth of an economy through their lending/credit facilities. They further stated that commercial bank loans and advances encourage the agricultural and 
manufacturing sectors' productivity. Hartarska et al. (2015) investigated relation between commercial bank credit and economic growth for the period 1991-2010. They contended a positive relation between agricultural lending and economic growth in the US context. Further, they stated that the financial support for agricultural sector is justified through its significant contribution to the economic growth. Moreover, Ghosh (2016) examined the relation between real estate loans and economic growth and findings divulged that credit distribution to the real estate sector is significant in explaining the economic growth in the US context. Further findings revealed that construction, land development, and single-family residential loans are most significant for the economic growth. Alejandro and Guerra (2017) studied the relation between banking credit and economic growth in Mexican context and the findings revealed a unidirectional causality from economic growth to the bank credit in the short run.

Misra, Chavan, and Verma (2016) studied the impact of agricultural credit on economic growth. The findings revealed a positive relation between credit distribution to the agriculture sector and economic growth in India. Zhang, Zhai, and Sun (2018) investigated the relation between bank lending and economic growth in 40 emerging and developing markets. Their findings revealed a positive relation between credit distribution and economic growth, but a weaker relationship is emerged when there is a high level of leasing distributions from the commercial banks. Hence, the empirical literature clearly shows that the banking industry is playing a crucial role in an economy by providing credit facilities (Chinweoke et al., 2015; Burzynska, 2009; Galeano \& Feijo, 2012). It significantly supports to develop the real sector of an economy through exposure to various kinds of risks. Thus, the banks should balance the risk exposure and credit utilization in order to achieve a sustainable development of an economy (Kumar, Batra, \& Deisting, 2016). The empirical contradictory evidences in other countries and paucity of studies conducted in the Sri Lankan context provide the rationale for this study. Therefore, to address the literature gap, the researchers of this study attempt to examine the impact of sectoral distribution of commercial bank credit on economic growth of Sri Lanka. 


\section{Methodology}

Dewasiri, Weerakoon Banda, and Azeez (2018) argue that the research problem and/or questions drive the methodology of a study. For instance, if the research problem is descriptive, comparative, relationship bound, or historical in nature, Onwuegbuzie and Leech (2006) recommended the quantitative methodology for such inquiry. Accordingly, this study formulated its research problem in the descriptive form (what) and thus proceeded with a quantitative inquiry. The period of the study is confined to 13 years from 2005 to 2017. The data points were collected on a quarterly basis from Licensed Commercial Banks in Sri Lanka and verified from the monthly bulletin of the CBSL from 2005 to 2017. The sample consists of 26 licensed commercial banks and accounted for 32 percent of the population (81 financial institutions). It could be considered as a limitation of the current study. The Cobb-Douglas theory is used in estimating economic growth of an economy as stated in equation 1 (Ngoc; 2008, Fernando \& Rajapaksha, 2018).

$\mathrm{Y}=\mathrm{f}(\mathrm{K}, \mathrm{L})$

Where;

$\mathrm{Y}=$ Real output / Economic growth

$\mathrm{K}=$ Total capital inputs

$\mathrm{L} \quad=$ Total labour Inputs

Here, we extended the estimation incorporating distribution of commercial bank credits as proxies to measure capital inputs as incorporated by Mulu (2012), Burzynska, (2009), Hartarska et al. (2015), and Ghosh (2016) as stated in the equation 2.

$\mathrm{Y}=\mathrm{f}(\mathrm{CAGRI}, \mathrm{CSER}, \mathrm{CIN}, \mathrm{CCON}, \mathrm{L})$

Where;

$\mathrm{Y}=$ Economic Growth proxied by $\log$ of Gross Domestic Production (GDP)

CAGRI $=$ Credit distribution to the Agricultural Sector

CSER = Credit distribution to the service sector

CIN = Credit distribution to the industry sector

CCON = Credit distribution to the consumption sector

$\mathrm{L} \quad=$ Labour force proxied by $\log$ of number of labours 
The conceptual model of the study is stated in Figure 1.

Figure 1: Conceptual Framework of the Study

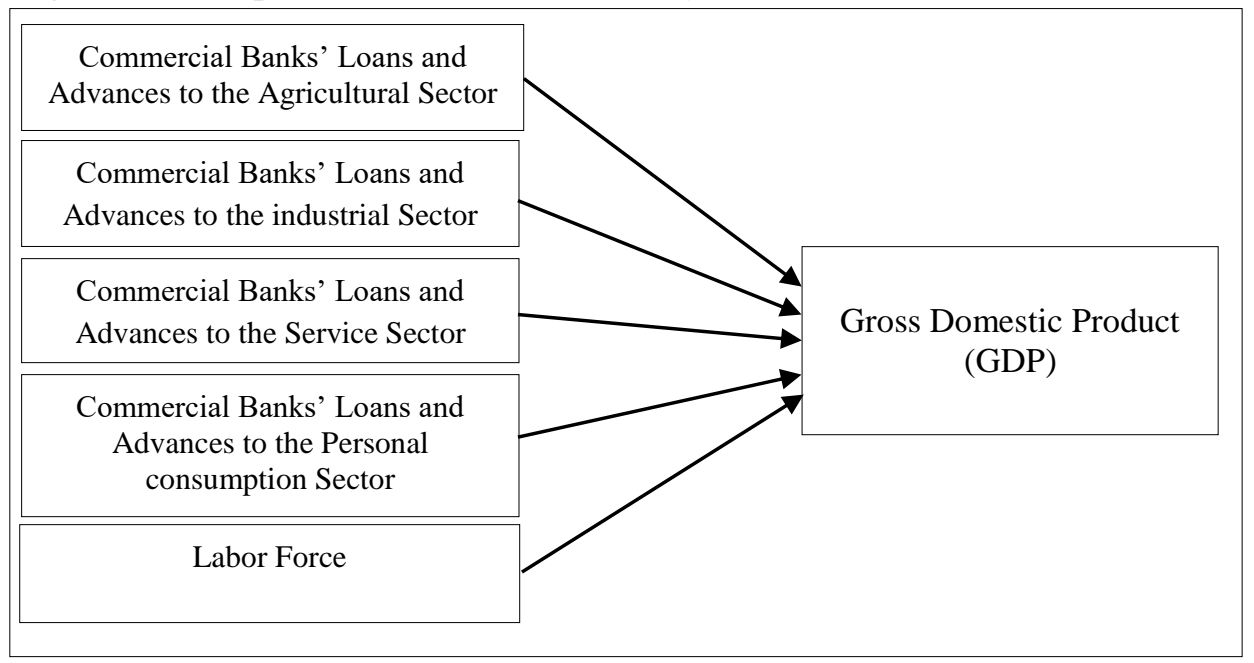

The literature review indicated that there is a significant impact from sectoral distribution of commercial bank credit facilities on economic growth in a country (Chinweoke et al., 2015; Burzynska, 2009; Galeano and Feijo, 2012). Hence, the following hypotheses were formulated to achieve the objectives of the study.

$\mathbf{H}_{1}$ : There is a short-term impact from Commercial Bank sectoral credit distribution and labor force on the economic growth of Sri Lanka.

$\mathbf{H}_{2}$ : There is a long-term impact from Commercial Bank sectoral credit distribution and labor force on the economic growth of Sri Lanka.

\section{Model Specification}

The Auto-regressive Distributed Lag (ARDL) model is used to investigate short and long run impact of sectoral distribution of commercial bank credit facilities on economic growth. The ARDL model is used to measure economic growth in the previous literature. For instance, Fernando, Silva, Naranpanawa and Gurusinghe (2017) investigated the relation between public debt and economic growth, Fernando and Rajapaksha (2018) investigated the relation between foreign direct investment (FDI) and 
economic growth in the Sri Lankan context. The ARDL model is a key to overcome the endogeneity problem by employing lag for the dependent variable and lags and leads for independent variables. Moreover, ARDL model is highly recommended for both small and large sample studies as emphasized by Fernando et al. (2017). The model specification of Equation (2) could be described as follows.

$\Delta \ln Y_{t}=a+\sum_{j=1}^{n 1} b_{j} \Delta \ln Y_{t-j}+\sum_{j=0}^{n 2} y_{j} \Delta \ln C D R_{t-j}+\sum_{j=0}^{n 3} \varepsilon_{j} \Delta \ln L B R_{t-j}+\sum_{j=0}^{n 4} \delta_{j} \Delta X_{t}+$

Continuation.... $\varpi_{1} \ln Y_{t-1}+\varpi_{2} \ln C D R_{t-1}+\varpi_{3} \ln L B R_{t-1}+\varpi_{4} \ln X_{t}+\varepsilon_{t}$

Where, $\operatorname{lnYt}$ represents the natural $\log$ values of real GDP in year $t, \operatorname{lnYt}-\mathrm{j}$ denotes natural log value of real GDP in year $t-j(j=1 \sim 3)$, lnCDRt-j denotes natural log values of commercial banks' credit distribution to the real sector in year $t-j(j=1 \sim 3)$, $\operatorname{lnLBR}$ represents natural log of labour force in year $t-j$ $(j=1 \sim 3)$. Xt represents other exogenous variables which could have impact on the economic growth. Here, the credit is measured through loans and advances issued by the commercial banks.

\section{Data Analysis and Discussion}

The data analysis is conducted in three stages. First, descriptive statistics, normality tests, and unit root tests with structural breaks are presented. Then, ARDL test is performed to test the short and long run impact of sectoral distribution of commercial bank credit on economic growth. Third, CUSUM tests are performed to confirm the stability of the ARDL model. Fourth, regression assumptions are tested on the residuals.

\section{Descriptive Statistics and Normality of Data}

According to the results indicated in Table 1, the mean and the variability of the industrial sector credit is comparatively higher than the other real sectors. The consumption lending is higher than the agricultural sector. This reveals that the banking sector has given less priority to agricultural sector credit facilities. The Skewness of the data measures the symmetry of the data. The study sample data has a normal univariate distribution since Kurtosis values are ranged between -1.96 and +1.96 for all variables as 
emphasized by George and Mallery (2010). The estimated p-values of the Jarque-Bera tests $(\mathrm{P}>0.01)$ confirmed the normality of distribution of all variables at 1 percent significant level.

Table 1: Descriptive Statistics: GDP, Labour Force, Agricultural, Industrial, Service, and Personal Consumption Sectors ${ }^{1}$

Sample: 2005.Q1 2017Q4

\begin{tabular}{lcccccc}
\hline \hline & LN_AGRI & LN_CONS & LN_GDP & LN_IN & LN_LABOR & LN_SER \\
\hline \hline Mean & 11.82800 & 12.81070 & 14.21578 & 13.34480 & 15.91960 & 12.87600 \\
Median & 12.43890 & 13.02920 & 14.26570 & 13.28470 & 15.91560 & 12.87410 \\
Maximum & 13.02030 & 13.88630 & 15.01800 & 14.48700 & 16.01380 & 14.11720 \\
Minimum & 9.890000 & 11.35000 & 13.10970 & 12.33880 & 15.80890 & 11.65930 \\
Std. Dev. & 1.044000 & 0.752000 & 0.570600 & 0.619200 & 0.056000 & 0.721100 \\
Skewness & -0.694500 & -0.405600 & -0.370400 & 0.175800 & -0.082100 & 0.133200 \\
Kurtosis & 1.804600 & 1.827800 & 1.933600 & 1.949600 & 1.925500 & 1.875700 \\
& & & & & & \\
Jarque-Bera & 2.276000 & 4.403000 & 3.212500 & 2.658200 & 1.715400 & 2.892100 \\
Probability & 0.226300 & 0.110600 & 0.200600 & 0.264700 & 0.424100 & 0.235400 \\
Observations & 52 & 52 & 52 & 52 & 52 & 52 \\
\hline
\end{tabular}

\section{Stationarity of Data}

Next, the unit roots of the variables are tested to investigate the order of integration. Here, the Break point unit root tests and Augmented Dicky fuller Tests are performed in testing such stationary status of the time series data. As emphasized by Perron, (1989), traditional unit root tests are not suitable when there are structural breaks in the series. For instance, In Sri Lankan GDP, there is a structural break in 2009 due to the eradication of 30 year civil war. The results of the unit root tests are presented in Table 2.

The findings of the breakpoint unit root tests and ADF tests revealed that all of the variables are stationary at its levels $\left(\mathrm{I}_{0}\right)$ whereas credit distribution to the consumption sector is stationary at its $1^{\text {st }}$ difference. It is possible to proceed with the ARDL model since all of the variables are stationary in either at $\mathrm{I}_{0}$ or $\mathrm{I}_{1}$. Moreover, the Breakpoint unit root tests revealed that $2^{\text {nd }}$ quarter of 2009 became the common break point for both GDP and credit distribution to the consumption sector. Further, the $4^{\text {th }}$ quarter of 2008 emerged as a common break point for credit distribution to

\footnotetext{
${ }^{1}$ LN_AGRI represents the natural logarithm of credit distribution to the agricultural sector, LN_CONS represents the natural logarithm of credit distribution to the consumption sector, LN_GDP represents the natural logarithm of real GDP growth, LN_IN represents the natural logarithm of credit distribution to the industry sector, LN_LABOR represents the natural logarithm of labor force, and LN_SER represents the natural logarithm of credit distribution to the service sector.
} 
both service and agricultural sectors. The $3^{\text {rd }}$ quarter of 2009 is emerged as a breakpoint for labour force. Hence, those three structural breaks are controlled with the application of ARDL employing a common breakpoint from Q4:2008 to Q3:2009.

Table 2: The Unit Root Test Results

\begin{tabular}{|c|c|c|c|c|}
\hline \multirow[b]{2}{*}{ Variable } & \multicolumn{2}{|c|}{ Unit Root Tests } & \multicolumn{2}{|c|}{ Break Dates } \\
\hline & $\begin{array}{l}\text { ADF } \\
\text { Tests }\end{array}$ & $\begin{array}{l}\text { Break Point } \\
\text { Unit Root } \\
\text { Test }\end{array}$ & Trend Break & Break Dummy \\
\hline LN_GDP GROWTH & $\mathrm{Io}_{\mathrm{o}}{ }^{* * *}$ & $\mathrm{I}_{0}{ }^{* * *}$ & Q2:2009** & Q2:2009*** \\
\hline LN_AGDRICULTURE & $\mathrm{I}_{\mathrm{o}}^{* * *}$ & $\mathrm{I}_{0}{ }^{* * *}$ & Q4:2008*** & Q4:2008*** \\
\hline LN_INDUSTRY & $\mathrm{I}_{\mathrm{o}}{ }^{* * *}$ & $\mathrm{I}_{0}{ }^{* * * *}$ & Q4:2009 & Q4:2009*** \\
\hline LN_SERVICE & $\mathrm{I}_{\mathrm{o}}{ }^{* * * *}$ & $\mathrm{I}_{0}{ }^{* * *}$ & Q4:2008 $8^{* * *}$ & Q4:2008 ${ }^{* * *}$ \\
\hline LN_CONSUMPTION & $\mathrm{I}_{1}{ }^{* * *}$ & $\mathrm{I}_{1}{ }^{* * *}$ & Q2:2009 & Q2:2009*** \\
\hline LN_LABOR FORCE & $\mathrm{I}_{0}{ }^{* * *}$ & $\mathrm{I}_{0}{ }^{* * *}$ & Q3:2009** & Q3:2009*** \\
\hline LN_CAPITAL FOR. & $\mathrm{I}_{1}{ }^{* * *}$ & $\mathrm{I}_{1}{ }^{* * *}$ & Q4:2010 & Q4:2010*** \\
\hline
\end{tabular}

\section{The Auto-regressive Distributed Lag (ARDL) Model}

The ARDL model is performed to measure the short and long run impact of sectoral distribution of commercial bank credit on the gross domestic product (economic growth). The ARDL Error Correction Form is performed to test the short run impact whereas the ARDL Long Run Form and Bounds test is performed to test the long run equilibrium.

The findings of the ARDL Error Correction model (Table 3) revealed that 27 percent correction of the disequilibria in GDP growth is based on the shocks in the current period and it shows a slow adjustment in GDP growth after one-quarter period. Moreover, credit distribution to the service sector is significant and negatively related with the economic growth in the short run. Further, labour force shows a significant positive impact on economic growth in the short run whereas breakpoint shows a significant different impact on the economic growth. 
Table 3: Results of the ARDL Error Correction Form: Short Run

Selected Model Based on Schwarz Criteria (SC): ARDL $(5,0)^{\text {a }}$

Dependent Variable

LN_GDP GROWTH

Included Observations

47

Bound Test F Statistics for small samples with one endogenous variable ${ }^{\mathrm{b}}$

$3.90^{* *}$

Variable

Coefficient Std. Error

t-Statistic

Prob.

(LN_GDPGRWOTH(-1))

$-0.044$

0.1316

$-0.3361$

0.7388

(LN_GDPGRWOTH(-2))

$-0.3964$

0.1256

$-3.1561$

$0.0033^{* * *}$

(LN_GDPGRWOTH(-3))

$-0.1899$

0.1194

$-1.5911$

0.1208

(LN_GDPGRWOTH(-4))

0.2687

0.1192

2.2534

$0.0306^{* *}$

Endogenous Regress ${ }^{2}$

LN_IN

0.0158

0.0258

0.6123

0.5484

Exogenous Regresses

\begin{tabular}{lrrrl}
\hline LN_LABOR & 0.3772 & 0.0972 & 3.8784 & $0.0004^{* * *}$ \\
LN_SER & -0.1561 & 0.0421 & -3.7048 & $0.0007^{* * *}$ \\
LN_AGRI & 0.0146 & 0.0149 & 0.9783 & 0.3346 \\
D(LN_CONS) & 0.0055 & 0.0673 & 0.0823 & 0.9348 \\
Break_Q42008-Q32009 & -0.083 & 0.022 & -3.7678 & $0.0006^{* * *}$ \\
CointEq(-1) & -0.2732 & 0.0778 & -3.5187 & $0.0012^{* * *}$ \\
\hline
\end{tabular}

Notes: (a) The model is estimated with a trend and up to 8 lags of the dependent variable and one endogenous variable. The best model is selected employing the Schwarz Criteria after evaluation of 72 models; (b) The bound test statistic was adjusted for small samples. ***, ** significance at the 1 percent and percent respectively.

Table 4 represents the findings of the ARDL long run form and bounds test. The F statistics of the bounds test implies that the ARDL model is significant in explaining long run relationship at 5 percent significant level. Moreover, credit distribution to the industry sector shows a significant longterm impact on the economic growth. If the credit distribution to the industry sector is increased by 1 percent, there will be a 0.328 percent of GDP growth in the long run. In accordance with the Cobb-Douglas theory,

\footnotetext{
${ }^{2}$ The credit distribution to the industrial sector is significantly affecting to the economic growth than the other sectors as emphasized by Chinweoke et al. (2015) and Waheed (2009). Hence, ARDL incorporated credit distribution to the industrial sector as an endogenous variable and other factors as exogenous variables.
} 
labour force is also shows a significant positive impact on the economic growth at 10 percent significant level.

The results presented in Table 3 and 4 confirmed that there is an impact of credit distribution to the real sector ${ }^{3}$ on economic growth in both short and long run. Hence, it is not possible to reject the $\mathrm{H}_{1}$ and $\mathrm{H}_{2}$ of the current study.

Table 4: ARDL Long Run Form and Bounds test

Selected Model Based on Schwarz Criteria (SC): ARDL $(5,0)^{\text {a }}$

Dependent Variable LN_GDP GROWTH

Included Observations $\quad 47$

Bound Test F Statistics for small samples with one endogenous variable

\begin{tabular}{lcccl} 
Variable & Coefficient & Std. Error & t-Statistic & Prob. \\
\hline (LN_GDPGRWOTH(-1)) & -0.0442 & 0.1370 & -0.3229 & 0.7487 \\
(LN_GDPGRWOTH(-2)) & -0.3964 & 0.1298 & -3.0525 & $0.0043^{* * *}$ \\
(LN_GDPGRWOTH(-3)) & -0.1899 & 0.1228 & -1.5460 & 0.1311 \\
(LN_GDPGRWOTH(-4)) & 0.2687 & 0.1259 & 2.1330 & $0.0400^{* *}$ \\
Endogenous Regress & & & & \\
LN_IN & 0.3287 & 0.1218 & 2.6983 & $0.0107^{* *}$ \\
Exogenous Regresses & & & & \\
\hline LN_LABOR & 0.3772 & 0.2117 & 1.7817 & $0.0835^{*}$ \\
LN_SER & -0.1561 & 0.0925 & -1.6865 & 0.1006 \\
LN_AGRI & 0.0146 & 0.0177 & 0.8256 & 0.4146 \\
D(LN_CONS) & 0.0055 & 0.0702 & 0.0789 & 0.9375 \\
Break_Q42008-Q32009 & 0.0830 & 0.0260 & -3.1831 & $0.0031^{* * *}$ \\
\hline
\end{tabular}

Notes:(a) The model is estimated with a trend and up to 8 lags of the dependent variable and one endogenous variable. The best model is selected employing the Schwarz Criteria after evaluation of 72 models; (b) The bound test statistic was adjusted for small samples. $* * * * *$, and $*$ significance at the 1 percent, 5 percent and 10 percent respectively.

\section{Robustness of the Results}

An important aspect of ARDL estimation is identified as the stability of model. The cumulative square (CUSUM) and cumulative sum of square

\footnotetext{
${ }^{3}$ Real sector is defined as the overall sector comprising agricultural, service, industry, and consumption.
} 
(CUSUM of Square) tests were performed to test the model stability. The results are presented in figure 2 .

Figure 2: The Findings of the CUSUM and CUSUM of Squares Tests
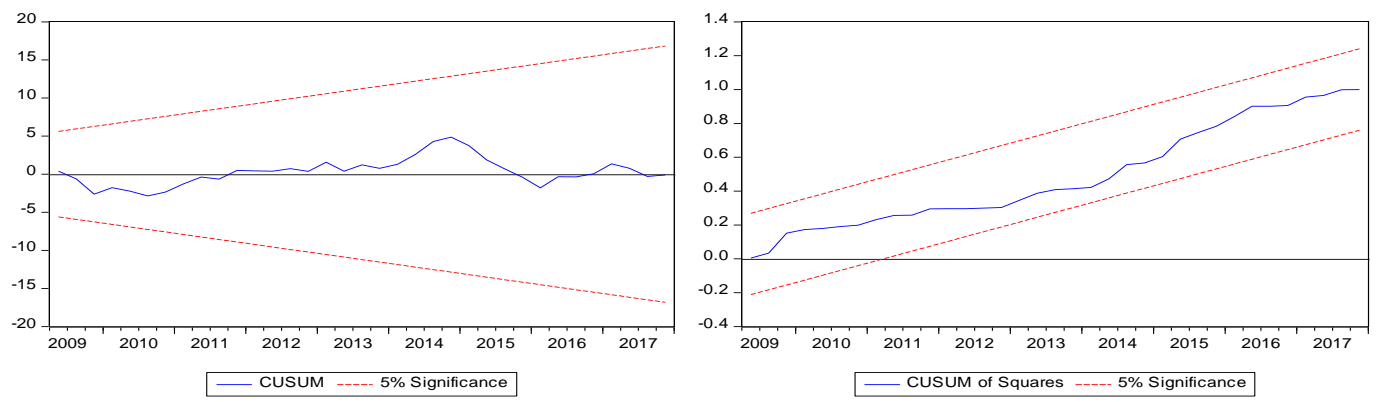

According to the findings both CUSUM and CUSUM of Square lie between critical boundaries at 5 percent significance level. Hence, the stability tests validate the robustness of the estimated $\operatorname{ARDL}(5,0)$ specification of the Model.

Further, several diagnostic tests were performed to test the ARDL assumptions while confirming validity of the model. First, error terms are tested for normal distribution. The findings of the Figure 3 indicate that error terms are normally distributed at 5 percent significant level.

Figure 3: Findings of the Jargue-Bera normality test.

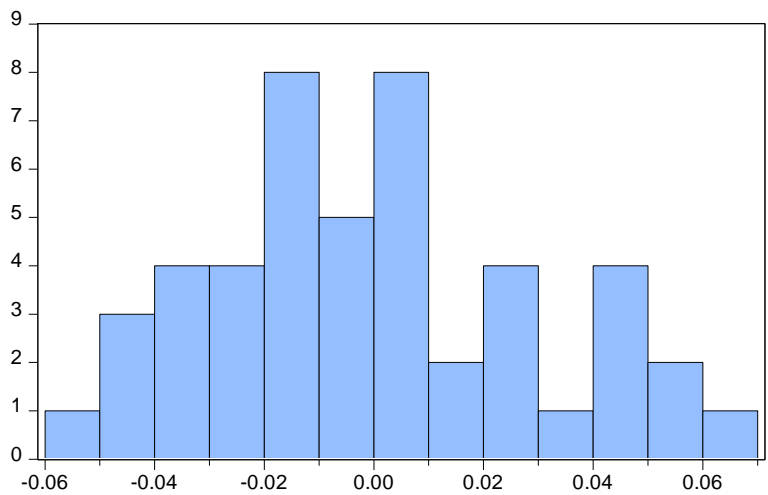

Series: Residuals

Sample 2006Q2 2017Q4

Observations 47

Mean $\quad-5.30 e-16$

Median $\quad-0.005140$

Maximum $\quad 0.060115$

Minimum $\quad-0.056713$

Std. Dev. $\quad 0.030026$

Skewness $\quad 0.314149$

Kurtosis $\quad 2.264074$

Jarque-Bera 1.833673

Probability $\quad 0.399782$ 
Second, Breusch-Godfrey serial correlation LM test was performed with 13 lags to test on the serial auto-correlation of the residuals. The findings depicted in table 5 indicate that there is no serial autocorrelation in the residuals at 1 percent significant level.

Table 5: Results of the Breusch-Godfrey serial correlation LM test

Null Hypothesis : No serial correlation up to 13 lags

\begin{tabular}{lrll}
\hline F Statistic & 0.5645 & Prob. F(13,22) & 0.8561 \\
Obs*R_squared & 11.7573 & Prob. Chi-Square(13 & 0.5476 \\
\hline
\end{tabular}

Third, Breusch-Pagan-Godfrey F-test was performed to test on the heteroscedasticity of the residuals. The results indicated in Table 6 show that residuals are homoscedastic at 1 percent significant level. Hence, the results of the diagnostic tests revealed that estimated ARDL model is free from violations of its assumptions.

Table 6: Results of the Breusch-Pagan-Godfrey F-test

\begin{tabular}{lrll}
\hline F Statistic & 0.5645 & Prob.F(13,22) & 0.8561 \\
Obs*R_squared & 11.7573 & Prob. Chi-Square(13 & 0.5476 \\
\hline
\end{tabular}

\section{Discussion}

In accordance with this study findings, Uzomba et al. (2014) found that the agricultural sector credit facilities had no impact on economic growth in Nigeria during 2002-2014 period due to farmers' high default rates, adverse weather conditions, unpredictable exposures and less infrastructure facilities. Waheed (2009) stated the economy of Pakistan is not facilitated via the agricultural industry and it should be improved by financial support for the economy to prosper and achieve sustainable development of the country. The problems of the Sri Lankan agricultural sector are, lack of land fragmentation, poor water management, storage facilities, and poor marketing opportunities (Wimalaratana, 2011). These are the major obstacles which freeze agricultural productivity. Thus, it is possible to argue that credit facilities become meaningless due to the other obstacles arising within the industry. 
According to short run ARDL results stated in Table 3, the credit distribution to the service sector has a significant negative effect on economic growth of Sri Lanka. In accordance with this finding, Triplett and Bosworth (2004) stated that the credit distribution to the service sector does not directly contribute to economic growth as it incurs high costs and a long time to render a sustainable contribution to an economy. The service industry consists of Transport, Communication and Information, Technology, Printing and Publishing, Education, Health, Shipping, Aviation and Freight Forwarding (Ministry of Finance, 2016). The transportation service sector has been experiencing a crisis situation for a long period due to high operational costs. Moreover, most of the road constructions and transport facilities were concentrated in the Western province (Ministry of Finance, 2016). The state banks' credit facilities were continuously injected into the marine and aviation services they are continually making losses to the country (CBSL, 2017). Further, commercial banks' credit distribution to the service sector is a small portion of the total credits facilitated to the same industry (CBSL, 2017). As a whole, the service industry has had an adverse impact in the Sri Lankan context due to the high costs of start-ups, maintenance and fixed employment costs, and non- representation of the overall credits to the industry.

The credit distribution to the industrial sector has the highest significant positive impact on the economic growth of Sri Lanka according to the ARDL long run analysis. In accordance with this study findings, Chinweoke et al. (2015) emphasized that industrial sector credit facilities by commercial banks contribute significantly to economic growth. Moreover, Waheed (2009) revealed that the banking sector lending for the industrial sector in Pakistan highly enhanced the economic growth. The present study agrees with these results.

\section{Summary, Conclusions and Implications}

The purpose of this study is to investigate the impact of sectoral distribution of commercial bank credit on economic growth of Sri Lanka. A quantitative study is carried out in achieving the objectives of the study. Based on the findings of the ARDL error correction model, it is possible to conclude that credit distribution to the agricultural, industry, and consumption sectors are not significant in explaining the short run economic growth of Sri Lanka. 
Further, credit distribution to the service sector, and labour force are significant in explaining economic growth in the short run. The long run analysis implies that there is a significant positive long run relationship between economic growth and credit distribution to the industrial sector.

This study has implications for bankers, policy makers, government, and future researchers. The bankers could develop their lending policies according to the impact of credit distribution of the respective industries on economic growth. For instance, they could assign high weightage to the credit distribution to industrial sector since it has the highest positive impact on economic growth.

The policy makers and government can develop policies and strategies in accordance with the findings of this study. For instance, if the requirement is long run economic growth, they should focus more on distributing credit facilities to the industry sector. Further, there should be a minimized effort for the service sector in the short run.

There are multiple implications for future researchers. First, the findings revealed that there is an inverse relationship between credit distribution to the service sector and economic growth. Hence, there is room for further investigation on the factors affecting such inverse relationship. Moreover, credit distribution to the agricultural sector was not significant in explaining the economic growth of Sri Lanka. Hence, the future researchers can investigate the reasons for such non-significance and make suggestions to improve the same. Further, this study is conducted using commercial banks as the sample. Future researchers can focus on all financial institutions for a more generalized and comprehensive picture about the research puzzle.

\section{Acknowledgement}

The authors wish to acknowledge with gratitude the support given by P. J. S. Fernando, Senior Lecturer, Department of Economics, University of Sri Jayewardenepura. 


\section{References}

Alejandro, E., \&Guerra, R. (2017). The economic growth and the banking credit in Mexico: Granger causality and short-term effects, 2001Q1 2016Q4. Economia Informa, 406, 46-58.

Burzynska, K. (2009). Financial development and economic growth: The case of Chinese banking sector. (Masters' Thesis). School of Economics and Management, Department of Economics, Lund University, Sweden.

Central Bank of Sri Lanka. (2017). Annual report 2017.Retrieved May 6, 2018 from https://www.cbsl.gov.lk/sites/default/files/cbslweb_documents/publicati ons/annual_report/2017/en/12_Chapter_08.pdf

Chinweoke, N., Chukwudinma, C., \& Elizabeth, N. C. (2015). Impact of commercial banks' loans and advances to agriculture and manufacturing sectors on the economic growth of Nigeria (1994-2013). International Journal of Arts \& Sciences, 8(5), 29-36.

Dewasiri, N.J. \& Kumarasinghe, P. (2014). Effect of macroeconomic variables on Stock returns with special reference to Colombo Stock exchange in Sri Lanka, in Gunarathne, P.S.M., Reed, W. R. \& Rathnayake, D.T. (eds.), Proceedings of the International Conference on Accounting \& Finance - 2014, TIIKM, Sri Lanka, 128-134.

Dewasiri, N.J., Weerakoon Banda, Y. K., \& Azeez, A.A. (2018). Mixed methods in finance research: The rationale and research designs. International Journal of Qualitative Methods, 17(1), 1-13.

Fernando, P.J. S., \& Rajapaksha, D.P. (2018). Redefining FDI-Growth relationship under liberalized economic policies: Empirical evidence from Sri Lanka. Sri Lankan Journal of Business Economics, 7, 20-39.

Fernando, P.J.S., Silva, H.N. D., Naranpanawa, A., \& Gunasinghe, C., (2017). Revisiting the debt growth nexus: Empirical evidence from Sri Lanka. Discussion Paper Series No. 2017-06, Department of Accounting, Finance and Economics, Griffith Business School, Australia.

Galeano, E. V., \& Feijó, C. (2012). Credit and economic growth: Evidence from a panel of regional data from the Brazilian economy in the 2000. Revista Econômica do Nordeste, 1(2), 201-218. 
George, D., \&Mallery, P. (2010). SPSS for windows step by step: A simple guide and reference 17.0 update. (10th ed.). Boston: Pearson.

Ghosh, A. (2016). Do real estate loans reflect regional banking and economic conditions? Journal of Financial Economic Policy, 8(1), 3763.

Hartarska, V., Nadolnyak, D., \& Shen, X. (2015). Agricultural credit and economic growth in rural areas. Agricultural Finance Review, 75(3), 302-312.

Köhler, M. (2012). Which banks are more risky? The impact of loan growth and business model on bank risk-taking. Discussion Papers 33/2012, Deutsche Bundes Bank.

Köhler, M. (2015). Which banks are more risky? The impact of business models on bank stability. Journal of Financial Stability, 16, 195-212.

Kumar, M., Batra, N., \& Deisting, F. (2016). Determinants of Priority Sector Lending: Evidence from Bank Lending Patterns in India.The International Journal of Business and Finance Research, 10(2), 55-80.

Ministry of Finance. (2016). Annual report 2016.Retrieved January 4, 2018 from

http://www.treasury.gov.lk/documents/10181/12870/2017.pdf/2bce4f3d -ebde-4409-b2b5-c8a0801b3edc.

Misra, R., Chavan, P., \&Verma, R. (2016). Agricultural credit in India in the 2000s: Growth, distribution and linkages with productivity. The Journal of Applied Economic Research, 10 (2), 169-197.

Mulu, M. J. (2012). The Effect of Commercial Bank Loans on the Economic Growth of Kenya. (Masters' Thesis). The University of Nairobi, Kenya.

Ngoc, P.M. (2008). The roles of capital and technological progress in Vietnam's economic growth. Journal of Economic Studies, 35(2), 200219.

Onwuegbuzie, A. J., \&Leech, N. L. (2006). Linking research questions to mixed methods data analysis procedures. The Qualitative Report, 11, 474-498.

Perron, P. (1989). The great crash, the oil price shock and the unit root hypothesis. Econometrica, 57, 1361-1401.

Rahman, M. M., Jongwanich, J., Venkatesh, S., \& Siengthai, S. (2012). Banking Sector reforms in Bangladesh and its impact. Asian Institute of Technology. (Master's Thesis, The University of Dhaka, Bangladesh). 
Retrieved from www.bankingandfinance.ait.ac.th/sites/default/files/.../report_mustafizur rahman.pdf

Rajakaruan, S. (2017). An investigation of factors affecting exchange rate fluctuations in Sri Lanka. Journal of South Asian Studies, 5(2), 101-115.

Rose, P.S. (2002). Commercial bank management (5th ed.). Boston: McGraw-Hill/Irwin.

Slow, M.R. (1956). A contribution to the theory of economic growth. The QuarterlyJournal of Economics, 70(1), 65-94.

Triplett, J. E., and Bosworth, B. P. (2004). Productivity in the US services sector: new sources of economic growth. Brookings Institution Press.

Uzomba, P. C., Chukwu, S. N., Jumbo, G. A., \& Nwankwo, N. U. (2014). An inquiring into the impact of deposit money banks' loans/advances on agricultural sector in Nigeria; 1980-2011. International Review of Social Sciences and Humanities, 7(2), 130-139.

Waheed, A. (2009). Financial Sector Reforms and Economic Growth: A Time Series Data Analysis for Pakistan. Discussion Papers 452/2009 Institute of Developing Economies, Japan External Trade Organization. BRAC University Dhaka Bangladesh.

Wimalarathana, V. (2011). Agriculture and Rural Developments in Sri Lanka. Colombo: Development Resource Centre, Department of Economics, University of Colombo.

Zhang, Y., Zhai, L., \& Sun, H. (2018). Does the level of financial leasing matter in the impact of bank lending on economic growth: Evidence from the global market (2006-2016). Finance Research Letters. Retrieved from https://www.sciencedirect.com/science/article/abs/pii/S1544612318303945 